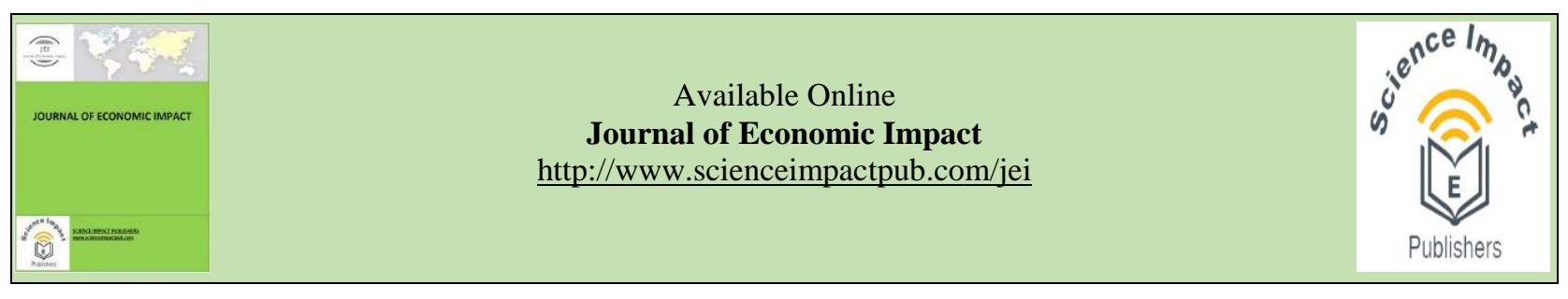

\title{
MICROFINANCE IS A NON-PRODUCTIVE AND EXPENSIVE SOURCE OF BORROWING: A CASE STUDY OF DISTRICT SARGODHA (PAKISTAN)
}

\author{
Tahir Mahmood ${ }^{\mathrm{a}, *}$, Allah Bakhsh ${ }^{\mathrm{b}}$ \\ ${ }^{a}$ Department of Economics, University of Lahore, Sargodha, Pakistan \\ ${ }^{\mathrm{b}}$ Institute of Agricultural Extension and Rural Development, University of Agriculture, Faisalabad, Pakistan
}

\section{HIGHLIGHTS}

- According to the results microfinance productivity is negative due to small loan size and high cost of borrowing.

- The major three factors of livestock productivity are the amount of interest rates, milk production and feed cost which are responsible to make efficient use of loan amount in its productivity.

- The productivity of the borrowing amount for large farm size was positive which is three times greater as compared to the microfinance for small farm size.

- The main reason for the high productivity of livestock financing in large farming is its large economies of size.

- Replacement of dilapidated equipment with modern equipment is one way to increase productivity in an organization.

- Productive capacity is a basic characteristic of large farm size and loan productivity depends on productive capacity.

- The study concluded that the microfinance banks in Pakistan have no significant impact on the productivity of livestock farming.

ABSTRACT
The study examines Pakistan's microfinance institutions' performance and checks the productivity of
microfinance institutions. For this purpose primary data was collected from a sample of 260 respondents from 6
microfinance banks in Sargodha District. This paper examined the livestock sector and the impact of microfinance
on livestock productivity. According to the results of the role of microfinance was non-productive due to the high
cost of borrowing, small loan size, high feed cost and use of the loan in a non-productive term. According to the
results microfinance productivity is negative due to small loan size and high cost of borrowing. While the
productivity of borrowing amount for large farm size is positive which is three times greater as compared to small
farm size. So results showed that the efficiency of production increase through large scale farming. Small loan
size and high cost of borrowing is a basic cause of negative microfinance productivity. Small loan size is not
benefited for investment because the loan amount is unable to meet the basic requirements at the farm level for
the increase in productivity of livestock farming. The main reason for the high productivity of livestock financing
in large farming is due to its economies of size. Replacement of dilapidated equipment with modern equipment
is one way to increase productivity in an organization. Large loan size decreases the inefficiency in input costs.
The major three factors of livestock productivity are the amount of interest rates, milk production and feed cost
which are responsible to make efficient use of loan amount in its productivity. Productive capacity is a basic
characteristic of large farm size and loan productivity depends on productive capacity.

Keywords: Microfinance; livestock, productivity; Sargodha; Pakistan.

Received: Sep 07, 2019; Accepted: Dec 30, 2019; Published: April 03, 2020.

* Correspondence: Department of Economics, University of Lahore, Sargodha, Pakistan

Email: tahir200001@gmail.com

\section{Introduction}

Microfinance, also known as microcredit, is a financial service that offers loans to poor's, small business owners who don't have access to traditional sources of capital. The goal of micro-financing is to provide individuals with money to invest in themselves or their business. The major objective of 
offering microfinance to small farmers in livestock by the micro-financing intuitions in Pakistan is to stop the exploitation of the poor caused by costly informal credit and to offer facilities to provide small loans to poor at a comparatively lower cost. One of the main features of a microcredit institution that distinguishes it from other commercial institutions is that it provides an alternative to informal lending; In fact, security is not required; There are simpler processes and less documentation; mostly group loans; simple and flexible repayment plans; Financial support for group members in case of emergency; The most vulnerable segments of the population are targeted, as well as group interactions with each other. At present, one of the main problems arising in the process of economic growth and development is to fight against poverty. Poverty is a multifaceted phenomenon that includes, but goes beyond, insufficient income. In many countries, the main goal of development has been to eliminate all aspects of poverty.

The concept of microfinance is a very effective tool in developed countries but if and only if the prime objective is to facilitate the poor segment of the society and if we deviate from this objective then results are very dangerous like the poor segment of society will become poorer and move towards hunger and starvation. The stark reality is that the poorest people in the world still lack access to sustainable financial services such as credit, savings, and Insurance. Most developing countries including Pakistan offering financing services to an only minor segments of the population. The majority do not receive credit from any financial institutions. Several studies have attempted to examine the role of microfinance on poverty alleviation and income generation by using different methodologies. Imai et al. (2010) showed a positive impact of microfinance on household's poverty reduction by using national household data of India. Berhane \& Gardebroek et al. (2011) showed that borrowing causally increased consumption and housing improvements. According to Mahmood et al. (2016) microfinance had been playing an important role in poverty reduction and improvement of the living standard of people in developing countries, like Pakistan. Positive assessment of the microfinance contribution towards poverty reduction has convinced many individuals, governments and NGOs to put efforts in supporting microfinance institutions and their activities (Dunford, 2006). Microfinance is a simple solution to poverty reduction (Rena et al., 2006). The demand for microfinance is growing day by day, particularly in underdeveloped countries due to the increasing rate of poverty (Bhatt et al., 2001). Westover (2008) failed to find a direct link between microfinance programs and poverty reduction.
Microfinance does not apply to the poor (Scully, 2000) or to the fact that the poor are deliberately excluded from microfinance programs (Simanowitz, 2002). The criticism of microfinance raises some criticism: first of all, the very poor often prefer not to participate in microfinance programs because they lack confidence or they consider loans too risky. The poorest of the poor, the so-called Poor indigenous people, are usually too risky to take credit for future investments. Second, indigenous poverty is often not accepted by other group members in group lending programs because they are considered as bad credit risk (Mosley and Hulme 1998). Thirdly, employees of microfinance organizations may prefer to leave the main poor, since lending is considered extremely risky for them. Finally, microfinance critics have doubts as to whether this has a positive effect on women. Studies showed that women were more reliable and have higher wage rates. Besides, women spend more on the education and health of their children (Pitt and Khandkar, 1998). That is why women play a major role in reducing family poverty. However, critics note that women are often forced to hand over the amount of loans to men who then use that loan for their purposes. This could be an additional burden for women if they are responsible for repayment (Goetz and Gupta, 1996). Various microfinance NGOs did not meet the needs of the poor for loans because of the high cost of lending programs (Henry, 2004). The current study underhand is conducted to check the impact of microfinance on livestock productivity.

\section{Methodology}

This study is based on primary data collected by the pretested questionnaire. The primary data was collected by a direct interviewing technique from 260 active clients of 6 microfinance institutions. These six microfinance institutions include Khushhali Microfinance Bank, Mobilink Microfinance Bank, Telenor Microfinance Bank, U Microfinance Bank, First Microfinance Bank and Finca Microfinance Bank in Sargodha district. Selected loan size is Rs.100000 and livestock farmer/investor purchases one animal against this loan. The questionnaire is distributed among the sampled responded and the data collection process was completed in 5 working days. The sample of the study consists of both male and female respondents within the age group as per standard average loan eligibility declared by selected microfinance institutions. All selected respondents predominantly engaged in agricultural activities especially linked with livestock farming. The simple random approach was used to select a sample for data collection. The data was collected by a simple random sampling technique and all microfinance institutions in the study area had an equal chance of being selected. 


\section{Cost of Borrowing}

The total charge taking on a debt obligation that can involve interest payments and other financing fees.

Formula: $\mathrm{COB}=\mathrm{I}+\mathrm{DC}+\mathrm{IC}+\mathrm{TC}+\mathrm{WTC}$

$\mathrm{COB}=$ Cost of borrowing

$\mathrm{I}$ is the rate of interest

$\mathrm{DC}$ is the documentation Cost

IC is the insurance Cost

$\mathrm{TC}$ is the traveling Cost

WTC is the withholding tax cost

\section{Cost of Purchased Animal}

Cost $=$ Feed + Vaccination + Opportunity cost of labor + Opportunity cost of land (per year)

\section{Output of Purchased Animal/ Rate of Return}

Output $=$ Milk in liter (per year) $\times$ Market Rate

\section{Rate of Return}

Rate of return is the amount of profit on an investment over a specific time, expressed as a proportion of the original investment. The time period is typically one year, in which the rate of return is referred to as annual return.
Net income from investment $=$ Output of animal or rate of returns - Cost of business

\section{Results and Discussion}

Some economists pointed out that small loan size is just supportive of income not for generating income and borrowers are unable to increase the standard of living in the long term. During the collection of primary data, it was observed that people were not interested in productive terms due to inefficient use of borrowing amount. It's also observed the money shortfall and repayment shortage was the main cause of clash in home and social structure. According to the opinion of sampled borrowers, the employee's behavior of microfinance institutions was very harsh for recovery. Collected data showed another picture of poverty in decreasing income level and savings because 128 respondents out of 260 repay the loan from the savings.

According to the results shown in table 1 microfinance productivity is negative due to small loan size and high cost of borrowing. Furthermore, the values explained output (milk) in a litter is 2403 and the market rate is 63.3 rupees but on the other side input cost (feed, vaccination, and land, labor) is very high. It is observed that small loan size and high cost of borrowing is a basic cause of negative microfinance productivity.

Table 1: Annual Productivity Analysis of Microfinance for Small Farm Size

\begin{tabular}{lc}
\hline Activity & Average Values (Rs) \\
\hline Net Interest Rate & $30.19 \%$ \\
Feed Cost (Per Year) & 100639 \\
Vaccination Cost (Per Year) & 4722.22 \\
Opportunity Cost of Land (Per Year) & 1900.37 \\
Opportunity Cost of Labor (Per Year) & 12838.9 \\
OutPut (Milk) in LTR (Per Year) & 2403 \\
Milk Sale Rate in Market & 63.3 \\
Productivity (Output-Cost) & 31543.88 \\
Productivity of Borrowing Amount & -676.6 \\
(Net Interest Rate - Productivity of Project) & \\
\hline
\end{tabular}

Source: Author's calculations

Small loan size is not benefited for investment because the loan amount is unable to meet the basic requirements at the farm level for the increase in productivity of livestock farming. 
Table 2: Productivity Analysis for Large Farm Size

\begin{tabular}{lc}
\hline Activity & Average Values (Rs) \\
\hline Net Interest Rates & $11.5 \%$ \\
Feed Cost (Per Year) & 77986.1 \\
Vaccination Cost (Per Year) & 4911.11 \\
Opp Cost of Land (Per Year) & 1611 \\
Opp Cost of Labor (Per Year) & 19600 \\
Output (Milk) in LTR (Per Year) & 2907.33 \\
Milk Sale Rate in Market & 62.8 \\
Productivity (Output-Cost) & 78442.36 \\
Productivity of Borrowing Amount & 66942.36 \\
\hline Net Interest Rate - Productivity of Project) & \\
\hline
\end{tabular}

Source: Author's calculations

According to results given in Table 2 productivity of the borrowing amount for large farm size is Rs. 66942.36 which is three times greater as compared to small farm size. So results showed that the efficiency of production increase through large scale farming.

The main reason for the high productivity of livestock financing in large farming is due to its economies of size. Replacement of dilapidated equipment with modern equipment is one way to increase productivity in an organization. Large loan size decreases the inefficiency in input costs. The major three factors of livestock productivity are the amount of interest rates, milk production and feed cost which are responsible to make efficient use of loan amounts in its productivity. Productive capacity is a basic characteristic of large farm size and loan productivity depends on productive capacity.

\section{Conclusions}

According to the results microfinance productivity is negative due to small loan size and high cost of borrowing. While the productivity of borrowing amount for large farm size is positive which is three times greater as compared to small farm size. So results showed that the efficiency of production increase through large scale farming.

\section{References}

Berhane, G., Gardebroek, C., 2011. Does microfinance reduce rural poverty? Evidence based on household panel data from northern Ethiopia. American Journal of Agricultural Economics, 93(1), 43-55.
Small loan size and high cost of borrowing is a basic cause of negative microfinance productivity. Small loan size is not benefited for investment because the loan amount is unable to meet the basic requirements at the farm level for the increase in productivity of livestock farming. The main reason for the high productivity of livestock financing in large farming is due to its economies of size. Replacement of dilapidated equipment with modern equipment is one way to increase productivity in an organization. Large loan size decreases the inefficiency in input costs. The major three factors of livestock productivity are the amount of interest rates, milk production and feed cost which are responsible to make efficient use of loan amounts in its productivity. Productive capacity is a basic characteristic of large farm size and loan productivity depends on productive capacity. Because in the existing microfinance sector of Pakistan the maximum loan size is 50000 to 100000 rupees. This small amount of loans in the livestock sector is unable to make productive contributions to the livestock sector. The absence of government intervention in this sector is very alarming for our livestock growth because the institution's policies move towards its own profit maximization rather than poverty reduction through microfinance.

Bhatt, D.L., Chew, D. P., Hirsch, A. T., Ringleb, P. A., Hacke, W., Topol, E.J., 2001. Superiority of clopidogrel versus aspirin in patients with prior cardiac surgery. Circulation, 103(3), 363-368. 
Dunford, C., 2006. Evidence of microfinance's contribution to achieving the millennium development goals (pp. 1-23). Davis, CA: Freedom from Hunger, USA.

Goetz, A.M., Gupta, R.S., 1996. Who takes the credit? Gender, power, and control over loan use in rural credit programs in Bangladesh. World Development, 24(1), 45-63.

Henry, C.M., 2004. Financial Performances of Islamic versus Conventional Banks in Clement. The Politics of Islamic Finance, pp. 104-128.

Imai, K.S., Arun, T., Annim, S.K., 2010. Microfinance and household poverty reduction: New evidence from India. World Development, 38(12), 1760-1774.

Mahmood, T., Farooq, M., Hussain, A.T., Sattar, A., 2016. Impact of microfinance on income generation and living standards a case study of Dera Ghazi Khan division. Pakistan Economic and Social Review, 54(1), 73-80.

Mosley, P., Hulme, D., 1998. Microenterprise finance: is there a conflict between growth and poverty alleviation? World development, 26(5), 783-790.
Pitt, M., Khandkar, S.R., 1998. The impact of groupbased credit programs on poor households in Bangladesh: does the gender of participants matter? Journal of Political Economy, 106(5): 958-996.

Rena, R., Kefela, D., Ghirmai, T., 2007. Poverty and Microfinance in eritrea-a discourse. The Global Journal of Finance and Economics, 4(2), 147161.

Scully, N.D., 2000. Micro-Credit no panacea for poor women. Retrieved November 14, 2001, from Women's Microcredit Accountability Network (WOMAN), in the Development Gap web site http://www.igc.org/dgap/micro.html

Simanowitz, A., 2002. Microfinance for the poorest: A review of issues and ideas for contribution of Imp-Act. Improving the impact of microfinance on Poverty: An Action Research Programme, University of Sussex, Brighton.

Westover, J., 2008. The record of microfinance: The effectiveness/ineffectiveness of microfinance programs as a means of alleviating poverty. Electronic Journal of Sociology, 12(1), 1-8. 